\title{
New $\beta$-Caryophyllene-Derived Terpenoids from the Soft Coral Sinularia nanolobata
}

\author{
Atallah F. Ahmed, ${ }^{\dagger, \ddagger}$ J ui-H sin Su, ${ }^{\dagger}$ Ru-Ting Shiue, ${ }^{\dagger}$ Xin-J ie Pan, ${ }^{\dagger}$ Chang-Feng Dai,,${ }^{\S}$ Yao-Haur Kuo, ${ }^{\perp}$ and \\ J yh-Horng Sheu*,t \\ Department of Marine Resources, National Sun Yat-Sen University, Kaohsiung 804, Taiwan, Republic of China, \\ Department of Pharmacognosy, Faculty of Pharmacy, Mansoura University, Mansoura 35516, Egypt, \\ Institute of Oceanography, National Taiwan University, Taipe 106, Taiwan, Republic of China, and \\ National Research Institute of Chinese Medicine, Taipei 112, Taiwan, Republic of China
}

Received J une 26, 2003

Two new norsesquiterpenoids, nanonorcaryophyllenes A (1) and B (2), two new diterpenoids, nanolobatins $A(3)$ and B (4), and a novel norditerpenoid, nanolobatin C (5), were isolated from the n-hexane extract of the Taiwanese soft coral Sinularia nanolobata. Also, two new furanone derivatives, 6 and 7, were isolated for the first time from natural sources. The structures of $\mathbf{1 - 5}$ were elucidated on the basis of extensive spectroscopic analyses and by comparison of the spectral data with those of the related metabolites. Nanonorcaryophyllenes A (1) and B (2) were characterized as 13-norcaryophyllenes that lack a methyl group at C-11, while nanolobatin C (5) represents the first example of a xeniaphyllanebased 17-norditerpenoid. The cytotoxicity of $\mathbf{1 - 6}$ against the growth of a limited panel of cancer cell lines is also described.

Soft corals belonging to genus Sinularia (Alcyoniidae) have been found to be a rich source of structurally unique and biologically active diterpenoi ds ${ }^{1}$ and norditerpenoids. ${ }^{1,2}$ A previous study on a J apanese sample of Sinularia nanol obata Verseveldt resulted in the isolation of several cytotoxic amphilectane-type diterpenoids, sinulobatins. ${ }^{3}$ During the course of our screening of bioactive metabolites from marine organisms, ${ }^{2,4-7}$ an investigation on the chemical constituents of S. nanol obata from Tai wanese waters has afforded two xeniaphyllane-type ${ }^{8}$ diterpenoids, nanolobatins A (3) and B (4). A novel norditerpenoid, nanolobatin C (5), has also been isolated and identified as the first 17-norxeniaphyllane. Although xeniaphyllanes have been known as the secondary metabolites of soft corals of Xenia, ${ }^{9}$ Nephthea, ${ }^{8}$ and Cespitularia, ${ }^{10}$ this is the first report on metabolites of this type from the genus Sinularia. F urthermore, two norsesquiterpenes, nanonorcaryophyllenes A (1) and B (2), and two furanone derivatives, 6 and 7, were also isolated in the present study. The structures of 1-5 were elucidated on the basis of extensive spectroscopic analyses, and their relative stereochemistries were deduced by the assistance of NOESY experiments and by comparison of the NMR data with those of related xeniaphyllene and $\beta$-caryophyllene-derived metabolites. ${ }^{8-16}$

In addition to the isolation and structural elucidation of these compounds, in vitro cytotoxic activities of metabolites 1-6 against KB (human oral epidermoid carcinoma), Hepa59T/NGH (human liver carcinoma), NCI-H661 (human lung large cell carcinoma), Hela (human cervical epitheloid carcinoma, DLD-1 (human colon adenocarcinoma), and Med (human medulloblastoma) cell lines also have been evaluated.

\section{Results and Discussion}

The minced tissues of S. nanol obata were successively extracted with $\mathrm{n}$-hexane and dichloromethane. The residue

* To whom correspondence should be addressed. Tel: 886-7-5252000, ext. 5030. Fax: 886-7-5255020. E-mail: sheu@mail.nsysu.edu.tw.

+ National Sun Yat-Sen University.

¥ Mansoura University.

$\S$ National Taiwan University.

${ }^{\perp}$ National Research Institute of Chinese Medicine.
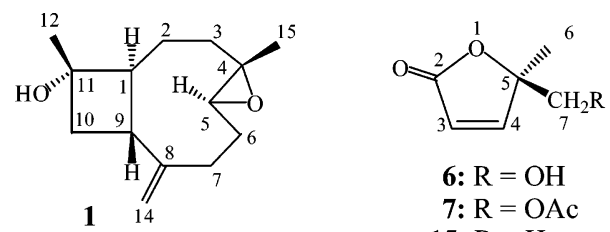

6: $\mathrm{R}=\mathrm{OH}$

7: $\mathrm{R}=\mathrm{OAc}$

15: $\mathrm{R}=\mathrm{H}$
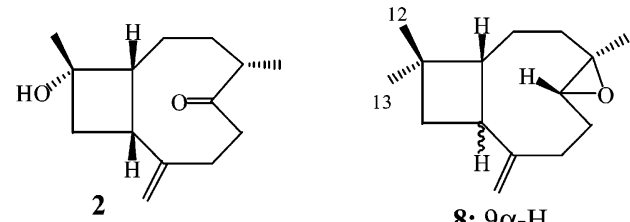

8: $9 \alpha-\mathrm{H}$

9: $9 \beta-\mathrm{H}$
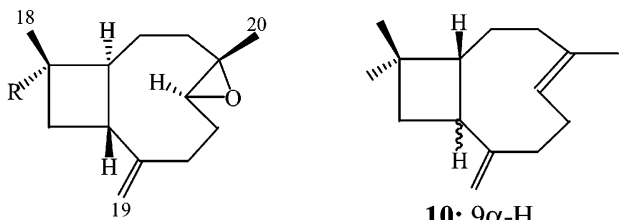

10: $9 \alpha-\mathrm{H}$

11: $9 \beta-\mathrm{H}$<smiles>[R]#CC(C)=CCCCC</smiles><smiles>CC(=O)C=CC(C)(C)O</smiles>

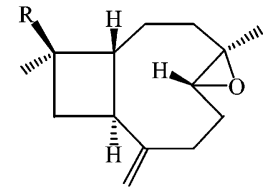

12: $\mathrm{R}=\mathrm{OH}$

14: $\mathrm{R}=\mathrm{COOH}$

16: $\mathrm{R}=\mathrm{CH}_{3}$<smiles>CCC(=O)CCC(C)O[R4]#[SH]</smiles>

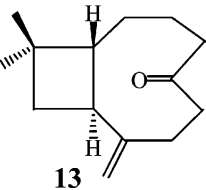

of the dichloromethane layer was further extracted with n-hexane. The combined n-hexane extract was concen- 
Table 1. ${ }^{13} \mathrm{C}$ NMR Chemical Shifts of Compounds $\mathbf{1}-\mathbf{5}, \mathbf{8},{ }^{11}$ and $\mathbf{1 4}^{12}$

\begin{tabular}{|c|c|c|c|c|c|c|c|}
\hline no. & $\mathbf{1}^{\mathrm{a}}$ & $2^{\mathrm{a}}$ & $3^{a}$ & $4^{a}$ & $5^{b}$ & $8^{c}$ & $14^{\mathrm{d}, \mathrm{e}}$ \\
\hline 1 & $53.7(\mathrm{CH})^{f}$ & $56.1(\mathrm{CH})$ & $49.8(\mathrm{CH})$ & $45.3(\mathrm{CH})$ & $45.3(\mathrm{CH})$ & $50.8(\mathrm{CH})$ & $47.7 *(\mathrm{CH})$ \\
\hline 2 & $26.5\left(\mathrm{CH}_{2}\right)$ & $26.5\left(\mathrm{CH}_{2}\right)$ & $27.9\left(\mathrm{CH}_{2}\right)$ & $28.2\left(\mathrm{CH}_{2}\right)$ & $28.0\left(\mathrm{CH}_{2}\right)$ & $27.2\left(\mathrm{CH}_{2}\right)$ & $29.8 * *\left(\mathrm{CH}_{2}\right)$ \\
\hline 3 & $38.9\left(\mathrm{CH}_{2}\right)$ & $30.8\left(\mathrm{CH}_{2}\right)$ & $39.1\left(\mathrm{CH}_{2}\right)$ & $38.6\left(\mathrm{CH}_{2}\right)$ & $38.5\left(\mathrm{CH}_{2}\right)$ & $39.1\left(\mathrm{CH}_{2}\right)$ & $38.5\left(\mathrm{CH}_{2}\right)$ \\
\hline 4 & 59.9 (C) & $48.0(\mathrm{CH})$ & 59.9 (C) & 59.6 (C) & 59.4 (C) & 59.8 (C) & 59.5 (C) \\
\hline 5 & $63.9(\mathrm{CH})$ & $217.0(\mathrm{C})$ & $63.9(\mathrm{CH})$ & $63.7(\mathrm{CH})$ & $63.6(\mathrm{CH})$ & $63.7(\mathrm{CH})$ & $63.5(\mathrm{CH})$ \\
\hline 6 & $30.3\left(\mathrm{CH}_{2}\right)$ & $42.2\left(\mathrm{CH}_{2}\right)$ & $30.2\left(\mathrm{CH}_{2}\right)$ & $30.1\left(\mathrm{CH}_{2}\right)$ & $30.0\left(\mathrm{CH}_{2}\right)$ & $30.2\left(\mathrm{CH}_{2}\right)$ & $29.7 * *\left(\mathrm{CH}_{2}\right)$ \\
\hline 7 & $29.2\left(\mathrm{CH}_{2}\right)$ & $32.1\left(\mathrm{CH}_{2}\right)$ & $29.8\left(\mathrm{CH}_{2}\right)$ & $29.7\left(\mathrm{CH}_{2}\right)$ & $29.5\left(\mathrm{CH}_{2}\right)$ & $29.8\left(\mathrm{CH}_{2}\right)$ & $35.1 * *\left(\mathrm{CH}_{2}\right)$ \\
\hline 8 & 150.5 (C) & 151.7 (C) & $151.8(\mathrm{C})$ & 150.8 (C) & $150.6(\mathrm{C})$ & $151.8(\mathrm{C})$ & $150.4(\mathrm{C})$ \\
\hline 9 & $44.9(\mathrm{CH})$ & $39.7(\mathrm{CH})$ & $48.8(\mathrm{CH})$ & $47.3(\mathrm{CH})$ & $47.2(\mathrm{CH})$ & $48.7(\mathrm{CH})$ & 47.3* $(\mathrm{CH})$ \\
\hline 10 & $42.6\left(\mathrm{CH}_{2}\right)$ & $41.9\left(\mathrm{CH}_{2}\right)$ & $38.6\left(\mathrm{CH}_{2}\right)$ & $35.3\left(\mathrm{CH}_{2}\right)$ & $35.1\left(\mathrm{CH}_{2}\right)$ & $39.8\left(\mathrm{CH}_{2}\right)$ & $27.5^{* *}\left(\mathrm{CH}_{2}\right)$ \\
\hline 11 & 71.1 (C) & 71.0 (C) & 36.0 (C) & 47.8 (C) & 48.2 (C) & 34.0 (C) & $41.8(\mathrm{C})$ \\
\hline 12 & $21.5\left(\mathrm{CH}_{3}\right)$ & $21.3\left(\mathrm{CH}_{3}\right)$ & $44.4\left(\mathrm{CH}_{2}\right)$ & 203.7 (C) & $213.1(\mathrm{C})$ & $29.9\left(\mathrm{CH}_{3}\right)$ & $182.8(\mathrm{C})$ \\
\hline 13 & & & $22.4\left(\mathrm{CH}_{2}\right)$ & $120.2(\mathrm{CH})$ & $32.5\left(\mathrm{CH}_{2}\right)$ & $21.6\left(\mathrm{CH}_{3}\right)$ & $16.8^{* * *}\left(\mathrm{CH}_{3}\right)$ \\
\hline 14 & $113.9\left(\mathrm{CH}_{2}\right)$ & $112.2\left(\mathrm{CH}_{2}\right)$ & $128.9(\mathrm{CH})$ & $153.6(\mathrm{CH})$ & $29.6\left(\mathrm{CH}_{2}\right)$ & $112.7\left(\mathrm{CH}_{2}\right)$ & $114.0\left(\mathrm{CH}_{2}\right)$ \\
\hline 15 & $17.1\left(\mathrm{CH}_{3}\right)$ & $16.7\left(\mathrm{CH}_{3}\right)$ & 134.1 (C) & $71.2(\mathrm{C})$ & $70.3(\mathrm{CH})$ & $17.0\left(\mathrm{CH}_{3}\right)$ & $16.4^{* * *}\left(\mathrm{CH}_{3}\right)$ \\
\hline 16 & & & $61.6\left(\mathrm{CH}_{2}\right)$ & $29.6\left(\mathrm{CH}_{3}\right)$ & $20.2\left(\mathrm{CH}_{3}\right)$ & & \\
\hline 17 & & & $21.3\left(\mathrm{CH}_{3}\right)$ & $29.6\left(\mathrm{CH}_{3}\right)$ & & & \\
\hline 18 & & & $18.9\left(\mathrm{CH}_{3}\right)$ & $17.0\left(\mathrm{CH}_{3}\right)$ & $16.8\left(\mathrm{CH}_{3}\right)$ & & \\
\hline 19 & & & $113.0\left(\mathrm{CH}_{2}\right)$ & $115.0\left(\mathrm{CH}_{2}\right)$ & $114.1\left(\mathrm{CH}_{2}\right)$ & & \\
\hline 20 & & & $17.1\left(\mathrm{CH}_{3}\right)$ & $17.1\left(\mathrm{CH}_{3}\right)$ & $17.0\left(\mathrm{CH}_{3}\right)$ & & \\
\hline Ac & & & & & $\begin{array}{l}170.7(\mathrm{C}) \\
21.3\left(\mathrm{CH}_{3}\right)\end{array}$ & & \\
\hline
\end{tabular}

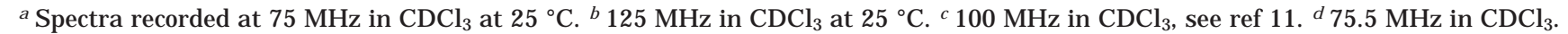
e $*, * *, * * *$ Assignments of chemical shifts may be exchanged between shifts indicated by the same superscript, see ref $12 .{ }^{f}$ Multiplicity deduced by DEPT and indicated by usual symbols. The values are in ppm downfield from TMS.

Table 2. ${ }^{1} \mathrm{H}$ NMR Chemical Shifts of Compounds 1, 2, and 8

\begin{tabular}{|c|c|c|c|}
\hline & $\mathbf{1}^{\mathrm{a}}$ & $2^{\mathrm{a}}$ & $8^{b, 11}$ \\
\hline $\mathrm{H}-1$ & $2.07 \mathrm{t}(10.0)^{\mathrm{c}}$ & $1.68 \mathrm{~m}$ & $1.76 \mathrm{t}(10.0)$ \\
\hline $\mathrm{H}-2 \alpha$ & $1.88 \mathrm{~m}$ & $1.24 \mathrm{dd}(15.0,8.4)$ & $1.32 \mathrm{~m}$ \\
\hline $\mathrm{H}-2 \beta$ & $1.43 \mathrm{~m}$ & $1.82 \mathrm{~d}(15.0)$ & $1.55-1.72 \mathrm{~m}$ \\
\hline $\mathrm{H}-3 \alpha$ & $1.04 \mathrm{dt}(4.8,13.0)$ & $1.80 \mathrm{t}(9.3)$ & $0.95 \mathrm{~m}$ \\
\hline $\begin{array}{l}\mathrm{H}-3 \beta \\
\mathrm{H}-4\end{array}$ & $2.10 \mathrm{~m}$ & $\begin{array}{l}1.65 \mathrm{~m} \\
2.54 \mathrm{~m}\end{array}$ & $2.10 \mathrm{dt}(3.5,12.5)$ \\
\hline $\mathrm{H}-5$ & 2.89 dd $(10.5,3.6)$ & & $2.87 \mathrm{dd}(10.6,4.1)$ \\
\hline$H-6 \alpha$ & $2.25 \mathrm{dt}(12.0,3.5)$ & $2.50-2.54 \mathrm{~m}$ & $1.42 \mathrm{~m}$ \\
\hline $\mathrm{H}-6 \beta$ & $1.34 \mathrm{~m}$ & $2.50-2.54 \mathrm{~m}$ & $\begin{array}{l}2.25 \text { ddd (16.4, } \\
7.8,4.1)\end{array}$ \\
\hline $\mathrm{H}-7 \alpha$ & $\begin{array}{l}2.35 \mathrm{ddd}(12.3,6.0 \text {, } \\
3.3)\end{array}$ & $2.42-2.50 \mathrm{~m}$ & $2.11 \mathrm{t}(12.4)$ \\
\hline $\mathrm{H}-7 \beta$ & $2.14 \mathrm{~m}$ & $2.42-2.50 \mathrm{~m}$ & $\begin{array}{c}2.34 \text { ddd (12.4, } \\
8.1,4.4)\end{array}$ \\
\hline $\mathrm{H}-9$ & $2.15 \mathrm{~m}$ & $1.89 \mathrm{dt}(7.5,9.3)$ & $2.61 \mathrm{q}(10.0)$ \\
\hline$H-10 \alpha$ & 2.02 dd $(10.2,7.5)$ & 1.77 t (9.6) & $1.55-1.72 \mathrm{~m}$ \\
\hline $\mathrm{H}-10 \beta$ & $1.88 \mathrm{~m}$ & $2.07 \mathrm{dd}(9.6,7.5)$ & $1.55-1.72 \mathrm{~m}$ \\
\hline $\begin{array}{l}\mathrm{H}-12 \\
\mathrm{H}-13\end{array}$ & $1.253 \mathrm{H}, \mathrm{s}$ & $1.163 \mathrm{H}, \mathrm{s}$ & $\begin{array}{l}0.983 \mathrm{H}, \mathrm{s} \\
1.003 \mathrm{H}, \mathrm{s}\end{array}$ \\
\hline $\mathrm{H}-14$ & $\begin{array}{l}4.901 \mathrm{H}, \mathrm{s} \\
5.001 \mathrm{H}, \mathrm{s}\end{array}$ & $4.932 \mathrm{H}, \mathrm{s}$ & $\begin{array}{l}4.85 \mathrm{~s} \\
4.97 \mathrm{~s}\end{array}$ \\
\hline $\mathrm{H}-15$ & $1.193 \mathrm{H}, \mathrm{s}$ & $1.043 \mathrm{H}, \mathrm{d}(6.9)$ & $1.203 \mathrm{H}, \mathrm{s}$ \\
\hline
\end{tabular}

a Spectra recorded at $300 \mathrm{MHz}$ in $\mathrm{CDCl}_{3}$ at $25^{\circ} \mathrm{C}$. b $400 \mathrm{MHz}$ in $\mathrm{CDCl}_{3}$, see ref 11 . ${ }^{\mathrm{C}}$ The J values (in parentheses) are in $\mathrm{Hz}$.

trated, and the residue was subjected to column chromatography over silica gel. Five fractions obtained were chosen for further purification by normal-phase HPLC to yield nanonorcaryophyllenes A (1) and B (2), nanol obatins $A-C(3-5)$, and the furanone derivatives 6 and 7 (see Experimental Section).

Nanonorcaryophyllene A (1) possesses the molecular formula $\mathrm{C}_{14} \mathrm{H}_{22} \mathrm{O}_{2}$ as revealed by its HREIMS (m/z 222.1617, $[\mathrm{M}]^{+}$) and NMR spectral data (Tables 1 and 2). Thus, 1 possesses four degrees of unsaturation. The infrared spectrum and MS data revealed the presence of a hydroxyl group in $\mathbf{1}\left(v_{\max } 3371 \mathrm{~cm}^{-1}\right.$ and $\left.\mathrm{m} / \mathrm{z} 204\left[\mathrm{M}-\mathrm{H}_{2} \mathrm{O}\right]^{+}\right)$. F rom the 14 carbon signals appearing in the ${ }^{13} \mathrm{C}$ NMR spectrum of 1, two methyls ( $\delta 17.1$ and 21.5), one trisubstituted epoxide $(\delta 59.9, \mathrm{C}$ and $63.9, \mathrm{CH})$, one double bond containing an exomethylene group ( $\delta 113.9, \mathrm{CH}_{2}$ and $\left.150.5, \mathrm{C}\right)$, and two methines ( $\delta 44.9$ and 53.7) could be assigned. Due to the presence of two $\mathrm{sp}^{2}$ carbon resonances in the ${ }^{13} \mathrm{C}$ NMR spectrum of $\mathbf{1}$ for one carbon-carbon double bond, $\mathbf{1}$ was considered to be a tricyclic compound. By the assistance of extensive 2D NMR study (COSY, HMQC, and $\mathrm{HMBC}$ ), the norcaryophyllene-based skeleton of $\mathbf{1}$ was proposed (Figure 1). Also, comparison of the ${ }^{1} \mathrm{H}$ and ${ }^{13} \mathrm{C}$ NMR spectral data of $\mathbf{1}$ with those of $\mathbf{8}^{11}$ (Tables 1 and 2) revealed that a methyl substituent at C-11 in 8 was replaced by a hydroxyl group in $\mathbf{1}$. Thus, the norsesquiterpenoid nature of $\mathbf{1}$ was fully established. The relative stereochemistry of $\mathbf{1}$ (Figure 2) was proposed on the basis of the key NOE correlations observed in the NOESY spectrum. Furthermore, it was found that the spectral data of (1R,4R,5R,9S, 11R )-4,5-epoxy-12-nor-8(14)-caryophyllen11-ol (12), 12 obtained previously by a microbial biotransformation of $\beta$-caryophyllene, were almost identical in all aspects with those of $\mathbf{1}$ except the sign of optical rotation. Nanocaryophyllene $A(\mathbf{1})\left([\alpha]_{D}+42.6^{\circ}\right)$ was thus enantiomeric with $12\left([\alpha]_{D}-36.3^{\circ}\right)$, and the absolute structure of 1 was established as (1S,4S,5S,9R,11S)-4,5-epoxy-12-nor8(14)-caryophyllen-11-ol.

Nanonorcaryophyllene B (2) has the same molecular formula, $\mathrm{C}_{14} \mathrm{H}_{22} \mathrm{O}_{2}$, as that of $\mathbf{1}$, as revealed from the HREIMS (m/z 222.1618, [M] ${ }^{+}$) and NMR spectral data (Tables 1 and 2). The existence of a ketone functional group $\left(v_{\max } 1700 \mathrm{~cm}^{-1}\right)$ and a hydroxyl moiety $\left(v_{\max } 3422 \mathrm{~cm}^{-1}\right.$ and $\mathrm{m} / \mathrm{z} 204\left[\mathrm{M}-\mathrm{H}_{2} \mathrm{O}\right]^{+}$) in 2 could be observed. The ${ }^{13} \mathrm{C}$ NMR spectrum also revealed that $\mathbf{2}$ is a norcaryophylenebased metabolite. Comparison of ${ }^{13} \mathrm{C}$ NMR spectral data of $\mathbf{2}$ and $\mathbf{1}$ (Table 1 ) indicated that the two carbons of the trisubstituted epoxide ( $\delta 59.9, \mathrm{C}$ and $63.9, \mathrm{CH})$ in 1 were replaced by a methine ( $\delta$ 48.0) and a ketone carbonyl ( $\delta$ $217.0, \mathrm{C})$ carbon. The proton resonating at $\delta 2.54(1 \mathrm{H}, \mathrm{m})$ that showed COSY correlations (Figure 1 ) with the signals of a secondary methyl at $\delta 1.04(3 \mathrm{H}, \mathrm{d}, \mathrm{J}=6.9 \mathrm{~Hz})$ and $\mathrm{H}_{2}-3(\delta 1.65, \mathrm{~m} ; 1.80, \mathrm{t}, \mathrm{J}=9.3 \mathrm{~Hz}$ ) was designated as $\mathrm{H}-4$. Furthermore, the HMBC correlations of $\mathrm{H}-4, \mathrm{H}_{3}-15, \mathrm{H}_{2}-3$, $\mathrm{H}_{2}-6$, and $\mathrm{H}_{2}-7$ with the carbon signal at $\delta 217.0 \mathrm{ppm}$ revealed the ketone functionality of $\mathrm{C}-5$. On the basis of the above findings and key COSY and HMBC correlations observed (Figure 1), the skel eton of $\mathbf{2}$ could be established unambiguously. 


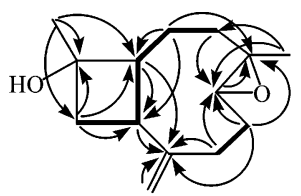

1
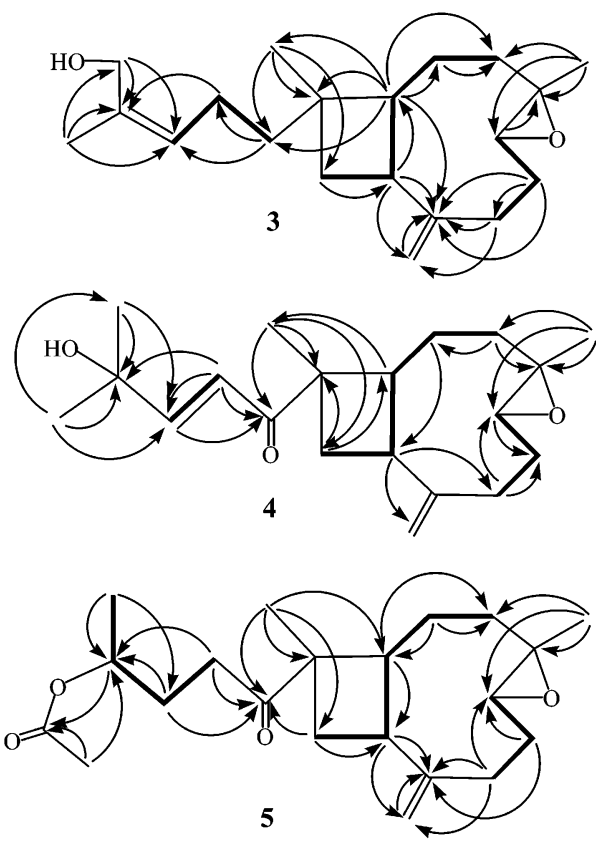

$-{ }^{1} \mathrm{H}-{ }^{1} \mathrm{H}$ COSY
$\rightarrow: \mathrm{HMBC}$

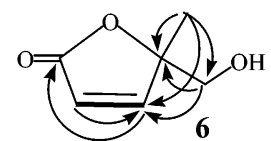

Figure 1. ${ }^{1} \mathrm{H}-{ }^{1} \mathrm{H}$ COSY and $\mathrm{HMBC}$ correlations for $\mathbf{1 - 6}$.
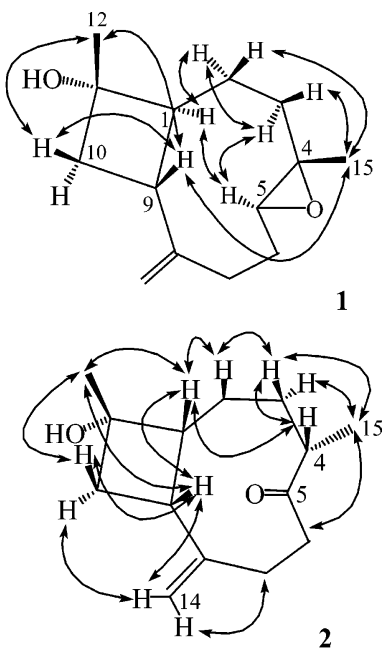

$\mathrm{NOE} \longleftrightarrow$

Figure 2. Key NOESY correlations of $\mathbf{1}$ and $\mathbf{2}$.

The relative stereochemistry of $\mathbf{2}$ (Figure 2) was deduced from the NOE interactions observed in the NOESY spectrum and by comparison of its ${ }^{1} \mathrm{H}$ and ${ }^{13} \mathrm{C}$ spectral data with those of the related compounds (9 and 11). ${ }^{13-16}$ Assuming the $\beta$-orientation of $\mathrm{H}-1$, it was found that $\mathrm{H}-1$ exhi bited a weak but meaningful NOE correlation with $\mathrm{H}-4$ $(\delta 2.54, \mathrm{~m})$. This observation is consistent with $\mathrm{H}-4$ being located on the $\beta$ face. Also, $\mathrm{H}-1$ exhibited NOE correlation with the $\beta$-proton at C-2 $(\delta 1.82, \mathrm{~d}, \mathrm{~J}=15.0 \mathrm{~Hz})$, which in turn showed interaction with $\mathrm{H}-3 \beta(\delta 1.65, \mathrm{~m})$, while the
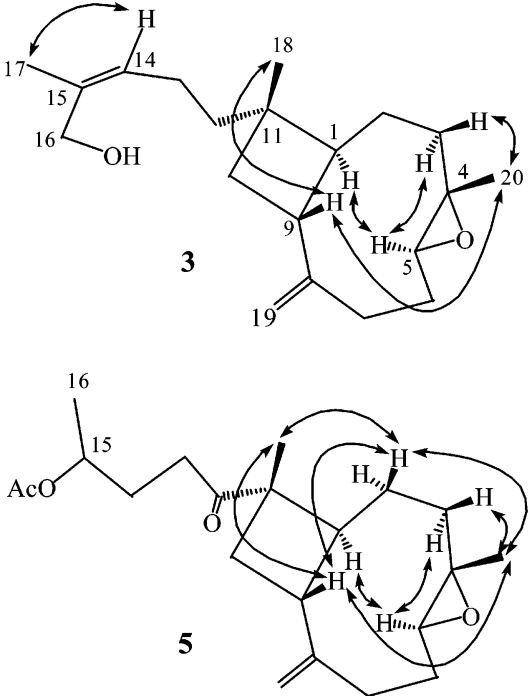

$\mathrm{NOE} \longleftrightarrow$

Figure 3. Key NOESY correlations of $\mathbf{3}$ and $\mathbf{5}$.

latter further correlated with $\mathrm{H}-4$. Thus, the $\beta$-orientation of $\mathrm{H}-4$ could be established unambiguously. $\mathrm{H}-1$ was also found to exhibit significant NOE interactions with $\mathrm{H}_{3}-12$ $(\delta 1.16,3 \mathrm{H}, \mathrm{s})$ and $\mathrm{H}-9(\delta 1.89, \mathrm{dt}, \mathrm{J}=7.5,9.3 \mathrm{~Hz})$, implying the $\beta$-orientations of $\mathrm{H}-9$ and the methyl substituent at $\mathrm{C}-11$. On the basis of the above findings and other key NOE interactions observed, the cis ring junction at C-1 and C-9 in $\mathbf{2}$ was established. Since only a few 9 -epi- $\beta$-caryophyllenes have been isolated from nature, ${ }^{13-17}$ further confirmation of the configuration at the ring junction was sought. It was found that a cis configuration of the ring junction (as in 9 and 11) induces an upfield shift at C-9 by almost more than $5.0 \mathrm{ppm}$ relative to the corresponding trans isomers (as in the cases of $\mathbf{8}$ and 10). ${ }^{13}$ Because the C- 9 of 2 showed a signal at $\delta 39.7 \mathrm{ppm}$, which is found to be upfield shifted by 5.2 and 6.0 ppm, respectively, in comparison to those of the related norsesquiterpenoids $\mathbf{1}\left(\delta_{\mathrm{C}-9}\right.$ $=44.9 \mathrm{ppm})$ and $\mathbf{1 3}\left(\delta_{\mathrm{c}-9}=45.7 \mathrm{ppm}\right){ }^{18}$ the cis ring junction in $\mathbf{2}$ was established unambiguously. Although at this stage we do not have sufficient data for determination of the absolute configuration, the relative stereochemistry of nanonorcaryophyllene B (2) could be fully assigned as (1R*,4S*,9R*,11S*)-5-oxo-13-nor-8(14)-caryophyllen-11ol on the basis of the above findings.

The new metabolite nanolobatin A (3) was obtained as a col orless oil. The molecular formula of $\mathbf{3}$ was established as $\mathrm{C}_{20} \mathrm{H}_{32} \mathrm{O}_{2}$ by HREIMS (m/z 304.2404, [M] $\left.]^{+}\right)$, thus requiring five degrees of unsaturation. The presence of a hydroxyl group in $\mathbf{3}$ was revealed from the absorption band at 3437 $\mathrm{cm}^{-1}$ and the ion peak at $\mathrm{m} / \mathrm{z} 286\left[\mathrm{M}-\mathrm{H}_{2} \mathrm{O}\right]^{+}$in the IR and EIMS spectra, respectively. The ${ }^{13} \mathrm{C}$ NMR spectrum of $\mathbf{3}$ showed signals of 20 carbons (Table 1), among which 11 carbons have very similar chemical shifts in comparison with those of the ring carbons (C-1 to C-11) of 8, suggesting that $\mathbf{3}$ could be a caryophyllenerelated diterpenoid. Detailed analyses of 2D NMR spectra of $\mathbf{3}$, focusing in particular on the interpretation of ${ }^{1} \mathrm{H}-{ }^{1} \mathrm{H}$ COSY, HMQC, and HMBC correlations, illustrated the gross structure of $\mathbf{3}$ as shown in Figure 1. Thus, the structure of $\mathbf{3}$ was determined to be consistent with a metabolite possessing a 4,5-epoxyxeniaphyllane skeleton.

The relative stereochemistry of $\mathbf{3}$ was determined on the basis of the NOE correlations observed in a NOESY spectrum (Figure 3). Assuming the $\alpha$-orientation of $\mathrm{H}-1$, it was found that $\mathrm{H}-1$ exhibited strong NOE interaction with 
$\mathrm{H}-5$, indicating the $\alpha$-orientation of $\mathrm{H}-5$. One proton attached at $\mathrm{C}-3$ and resonating at $\delta 0.94(\mathrm{dt}, \mathrm{J}=6.0,14.4$ $\mathrm{Hz}$ ) showed NOE correlation with $\mathrm{H}-5$ and was assigned as $\mathrm{H}-3 \alpha$. The other proton attached at $\mathrm{C}-3, \mathrm{H}-3 \beta(\delta 2.06$, $\mathrm{m})$, displayed NOE correlation with $\mathrm{H}_{3}-20$, which further interacted with $\mathrm{H}-9$, reveal ing the $\beta$-orientations of $\mathrm{H}-9$ and $\mathrm{H}_{3}-20 . \mathrm{H}_{3}-18$ showed NOE interaction with $\mathrm{H}-9$, but not with $\mathrm{H}-1$, and should be positioned on the $\beta$ face. Furthermore, the NOE correlations displayed between the $\mathrm{H}-14$ and $\mathrm{H}_{3}-17$ revealed the $\mathrm{Z}$ geometry of the 14,15-double bond. Therefore, the relative structure of nanol obatin A (3) was unambiguously established as in formula 3. As compound $\mathbf{3}\left([\alpha]_{\mathrm{D}}+15.0^{\circ}\right)$ is the prenylated derivative of $\mathbf{1}\left([\alpha]_{\mathrm{D}}\right.$ $+42.6^{\circ}$ ) and both are isolated from the same organism, it is reasonable to assign the same absolute configuration at C-1, C-4, C-5, C-9, and C-11 for $\mathbf{3}$ as that of $\mathbf{1}$. The structure of nanolobatin A (3) was thus determined as $(1 \mathrm{~S}, 4 \mathrm{~S}, 5 \mathrm{~S}$, 9R,11S,14Z )-4,5-epoxyxeniaphylla-8(19),14-dien-16-ol.

The second related diterpenoid metabolite, nanolobatin B (4), was also obtained as a colorless oil. Its HREIMS spectral data (m/z 318.2394) suggested the molecular formula $\mathrm{C}_{20} \mathrm{H}_{30} \mathrm{O}_{3}$, requiring six degrees of unsaturation. The infrared absorption band at $3640 \mathrm{~cm}^{-1}$ indicated the presence of a hydroxyl group. Comparison of ${ }^{13} \mathrm{C} N \mathrm{NR}$ spectral data of $\mathbf{4}$ with those of $\mathbf{3}$ (Table 1) revealed that $\mathbf{4}$ should be another xeniaphyllene-type diterpenoid and differs from 3 only in the isoprene tail (C-12 to C-18) portion of the molecule. It was found that $\mathbf{4}$ possesses a ketone carbonyl ( $\delta$ 203.7, C), a 1,2-disubstituted carboncarbon double bond $(\delta 120.2, \mathrm{CH}$ and 153.6, CH), and a carbon containing a tertiary hydroxyl group $(\delta 71.2, C)$. The downfield shift exerted at C-11 $(\delta 47.8, C)$ of 4 relative to that of $\mathbf{3}(\delta 36.0, \mathrm{C})$ allowed $\mathrm{C}-12$ to be assigned to the ketone carbonyl, as the similar magnitude of this downfield shift also was observed on comparison of ${ }^{13} \mathrm{C}$ NMR data of the known compounds $\mathbf{8}^{11}$ and $\mathbf{1 4}^{12}$ (Table 1 ). The E-1,2disubstituted double bond was revealed by the signals of two vicinal protons $(\delta 6.41,1 \mathrm{H}, \mathrm{d}, \mathrm{J}=15.3 \mathrm{~Hz} ; \delta 6.97,1 \mathrm{H}$, $\mathrm{d}, \mathrm{J}=15.3 \mathrm{~Hz}$ ). On the basis of the above observations and other key COSY and HMBC correlations (Figure 1), the molecular framework of $\mathbf{4}$ was established. Comparison of chemical shifts and J values of $\mathrm{H}-1, \mathrm{H}-5$, and $\mathrm{H}-9$ and chemical shifts of C-1, C-4, C-5, C-9, and C-11 of 4 with those of $\mathbf{3}$ and $\mathbf{5}$ (discussed later) indicated that 3-5 possess the same relative stereochemistries at C-1, C-4, C-5, C-9, and C-11. By comparison with one of the fermentation products of $\beta$-caryophyllene, (1R,4R, $5 \mathrm{R}, 9 \mathrm{~S}, 11 \mathrm{R})-4,5-$ epoxycaryophyll-8(14)-en-12-oic acid $(\mathbf{1 4})^{12}\left([\alpha]_{\mathrm{D}}-55.5^{\circ}\right)$, the prenylated derivative nanolobatin $B(4)\left([\alpha]_{D}+66.7^{\circ}\right)$ was finally defined as (1S,4S,5S,9R,11S,13E)-4,5-epoxyxeniaphylla-8(19),13-dien-12-on-15-ol, on the basis of the signs of optical rotations of these two compounds.

The novel norditerpene nanolobatin A (5) was isolated from a less polar fraction of the hexane extract. A mol ecular formula of $\mathrm{C}_{21} \mathrm{H}_{32} \mathrm{O}_{4}$ for $\mathbf{5}$ was suggested by the FABMS spectrum of 5, which exhibited a peak at $\mathrm{m} / \mathrm{z} 349[\mathrm{M}+$ $\mathrm{H}^{+}$, and ${ }^{13} \mathrm{C}$ and ${ }^{1} \mathrm{H}$ NMR spectral data (Tables 1 and 3). The HREIMS spectrum showed a strong ion peak at $\mathrm{m} / \mathrm{z}$ 288.2084, which corresponds to a fragment with a molecular formula $\mathrm{C}_{19} \mathrm{H}_{28} \mathrm{O}_{2}$ arising from the elimination of an equival ent of acetic acid. Infrared absorption bands at 1734 and $1700 \mathrm{~cm}^{-1}$ indicated that 5 possesses ester and ketone functionalities. Comparison of the ${ }^{13} \mathrm{C}$ NMR spectral data of $\mathbf{5}$ with those of $\mathbf{4}$ (Table 1 ) indicated that $\mathbf{5}$ has the same carbon skeleton as that of $\mathbf{4}$ from C-1 to C-12, while the 13,14-double bond in 4 was reduced. In addition to the presence of an acetate methyl group which showed a signal
Table 3. ${ }^{1} \mathrm{H}$ NMR Chemical Shifts of Compounds 3-5

\begin{tabular}{|c|c|c|c|}
\hline & $3^{a}$ & $4^{a}$ & $5^{b}$ \\
\hline $\begin{array}{l}\mathrm{H}-1 \\
\mathrm{H}-2 \alpha \\
\mathrm{H}-2 \beta\end{array}$ & $\begin{array}{l}1.83 \mathrm{t}(9.6)^{\mathrm{c}} \\
1.65 \mathrm{~m} \\
1.43 \mathrm{~m}\end{array}$ & $\begin{array}{l}2.46 \mathrm{t}(9.7) \\
1.85(10.8,8.7) \\
1.57 \mathrm{~m}\end{array}$ & $\begin{array}{l}2.41 \mathrm{t}(10.0) \\
1.77 \mathrm{dd}(14.5,3.0) \\
1.54 \mathrm{ddd}(14.5,10.5, \\
\quad 4.0)\end{array}$ \\
\hline$H-3 \alpha$ & $\begin{array}{l}0.94 \mathrm{dt}(6.0 \\
14.4)\end{array}$ & $1.12 \mathrm{dt}(4.8,14.0)$ & $1.07 \mathrm{dt}(5.0,13.0)$ \\
\hline $\begin{array}{l}\mathrm{H}-3 \beta \\
\mathrm{H}-5\end{array}$ & $\begin{array}{l}2.06 \mathrm{~m} \\
2.88 \mathrm{dd}(10.5 \text {, } \\
3.9)\end{array}$ & $\begin{array}{l}2.10 \mathrm{~m} \\
2.91 \mathrm{dd}(10.5,4.0)\end{array}$ & $\begin{array}{l}2.10 \mathrm{~d}(13.0) \\
2.90 \mathrm{dd}(10.5,4.0)\end{array}$ \\
\hline $\begin{array}{l}H-6 \alpha \\
H-6 \beta \\
H-7 \alpha \\
H-7 \beta \\
H-9 \\
H-10 \alpha \\
H-10 \beta \\
H-12 \alpha \\
H-12 \beta\end{array}$ & $\begin{array}{l}2.25 \mathrm{~m} \\
1.31 \mathrm{~m} \\
2.33 \mathrm{~m} \\
2.11 \mathrm{~m} \\
2.60 \mathrm{q}(9.4) \\
1.66 \mathrm{br} \mathrm{t} \mathrm{(9.0)} \\
1.66 \mathrm{br} \mathrm{t}(9.0) \\
1.26 \mathrm{~m} \\
1.38 \mathrm{~m}\end{array}$ & $\begin{array}{l}2.31 \mathrm{~m} \\
1.26 \mathrm{~m} \\
2.37 \mathrm{~m} \\
2.14 \mathrm{~m} \\
2.71 \mathrm{q}(9.3) \\
2.18 \mathrm{~m} \\
1.84 \mathrm{dd}(10.8,8.7)\end{array}$ & $\begin{array}{l}2.25 \mathrm{dt}(12.0,4.5) \\
1.33 \mathrm{~m} \\
2.31 \mathrm{dd}(12.0,5.5) \\
2.14 \mathrm{dd}(12.0,6.0) \\
2.68 \mathrm{q}(10.0) \\
2.10 \mathrm{t}(11.0) \\
1.77 \mathrm{t}(11.5)\end{array}$ \\
\hline $\begin{array}{l}H-13 \alpha \\
H-13 \beta\end{array}$ & $\begin{array}{l}1.97 q(8.0) \\
1.97 \mathrm{q}(8.0)\end{array}$ & $6.41 \mathrm{~d}(15.3)$ & $\begin{array}{l}2.43 \mathrm{~m} \\
2.38 \mathrm{~m}\end{array}$ \\
\hline $\begin{array}{l}\mathrm{H}-14 \\
\mathrm{H}-15\end{array}$ & $5.28 \mathrm{t}(7.0)$ & $6.97 \mathrm{~d}(15.3)$ & $\begin{array}{l}1.79 \mathrm{~m}, 1.84 \mathrm{~m} \\
4.89 \mathrm{br} t(6.3)\end{array}$ \\
\hline $\begin{array}{l}\mathrm{H}-16 \\
\mathrm{H}-17\end{array}$ & $\begin{array}{l}4.132 \mathrm{H}, \mathrm{s} \\
1.783 \mathrm{H}, \mathrm{s}\end{array}$ & $\begin{array}{l}1.383 \mathrm{H}, \mathrm{s} \\
1.383 \mathrm{H}, \mathrm{s}\end{array}$ & $1.233 \mathrm{H}, \mathrm{d}(6.5)$ \\
\hline $\begin{array}{l}\mathrm{H}-18 \\
\mathrm{H}-19\end{array}$ & $\begin{array}{l}1.033 \mathrm{H}, \mathrm{s} \\
4.861 \mathrm{H}, \mathrm{s} \\
4.971 \mathrm{H}, \mathrm{s}\end{array}$ & $\begin{array}{l}1.323 \mathrm{H}, \mathrm{s} \\
4.921 \mathrm{H}, \mathrm{s} \\
5.01 \mathrm{H}, \mathrm{s}\end{array}$ & $\begin{array}{l}1.293 \mathrm{H}, \mathrm{s} \\
4.921 \mathrm{H}, \mathrm{s} \\
5.011 \mathrm{H}, \mathrm{s}\end{array}$ \\
\hline $\begin{array}{l}\mathrm{H}-20 \\
\mathrm{AC}\end{array}$ & $1.203 \mathrm{H}, \mathrm{s}$ & $1.223 \mathrm{H}, \mathrm{s}$ & $\begin{array}{l}1.213 \mathrm{H}, \mathrm{s} \\
2.023 \mathrm{H}, \mathrm{s}\end{array}$ \\
\hline
\end{tabular}

a Spectra recorded at $300 \mathrm{MHz}$ in $\mathrm{CDCl}_{3}$ at $25^{\circ} \mathrm{C}$. b $500 \mathrm{MHz}$ in $\mathrm{CDCl}_{3}$ at $25^{\circ} \mathrm{C}$. ${ }^{\mathrm{c}}$ The $\mathrm{J}$ values (in parentheses) are in $\mathrm{Hz}$.

Table 4. Cytotoxicity of Terpenoid Metabolites 1-6a

\begin{tabular}{ccccccc}
\hline & \multicolumn{7}{c}{ cell lines ED $50(\mu \mathrm{g} / \mathrm{mL})$} \\
\cline { 2 - 7 } compd & Hepa59TNGH & KB & NCl-H661 & Hela & Med & DLD-1 \\
\hline $\mathbf{1}$ & $>20.0$ & $>20.0$ & $>20.0$ & $>20.0$ & $>20.0$ & $>20.0$ \\
$\mathbf{2}$ & 18.5 & $>20.0$ & $>20.0$ & $>20.0$ & $>20.0$ & 16.9 \\
$\mathbf{3}$ & 4.6 & 7.3 & $-\mathrm{b}$ & - & - & - \\
$\mathbf{4}$ & 8.3 & 7.6 & - & - & - & - \\
$\mathbf{5}$ & $>20.0$ & 19.5 & 19.0 & 15.9 & $>20.0$ & - \\
$\mathbf{6}$ & $>20.0$ & $>20.0$ & 15.7 & $>20.0$ & $>20.0$ & $>20.0$ \\
\hline
\end{tabular}

a Standard is doxorubicin with $\mathrm{ED}_{50}$ values of $0.47,0.25,0.29$ $0.41,0.57$, and $0.22 \mu \mathrm{g} / \mathrm{mL}$ against Hepa59T NGH, KB, NCl-H661, Hela, Med, and DLD-1, respectively. ${ }^{b}$ Not tested.

at $\delta 2.02(3 \mathrm{H}, \mathrm{s})$, it was found that there is only one secondary methyl attached at C-15 $(\delta 1.23, \mathrm{~d}, \mathrm{~J}=6.5 \mathrm{~Hz})$, thus indicating the norditerpenoid nature of $\mathbf{5}$. The molecular framework of $\mathbf{5}$ was further confirmed by the observed COSY and HMBC correlations (Figure 1).

The relative stereochemistries at C-1, C-4, C-5, C-9, and $\mathrm{C}-11$ in $\mathbf{5}$ were found to be the same as those of $\mathbf{3}$ on the basis of the NOE correlations observed in a NOESY spectrum (Figure 3). The chemical shifts of both C-1 protons in $\mathbf{4}(\delta 2.46, \mathrm{t}, \mathrm{J}=9.7 \mathrm{~Hz})$ and $\mathbf{5}(\delta 2.41, \mathrm{t}, \mathrm{J}=$ $10.0 \mathrm{~Hz}$ ) were found to be close to that of $\mathbf{1 4}(\delta 2.52, \mathrm{dd}, \mathrm{J}$ $=10.0,9.7 \mathrm{~Hz})^{12}$ and are significantly downfield shifted in comparison with those of $\mathbf{3}(\delta 1.83, \mathrm{t}, \mathrm{J}=9.6 \mathrm{~Hz})$ and $\mathbf{1 6}$ $(\delta 1.76, \mathrm{t}, \mathrm{J}=10.0 \mathrm{~Hz}){ }^{11}$ These data revealed that both C-1 protons of $\mathbf{4}$ and $\mathbf{5}$ are syn oriented relative to the carbonyl-containing substituents at C-10. From the above observations and other NOE interactions (Figure 3), the structure of nanolobatin $C(5)\left([\alpha]_{D}+21.0^{\circ}\right)$, which is produced together with $\mathbf{3}$ and $\mathbf{4}$ from the same organism, is thus elucidated as (1S,4S,5S,9R,11S)-4,5-epoxy-15-acetoxy-17-norxeniaphyll-8(19)-en-12-one.

In addition to the discovery of the above caryophyllenebased metabolites, two furanones, 6 and 7, were also isolated. The structures of these two compounds were established by 1D and 2D NMR experiments. Compound 6 was obtained as a colorless oil, $[\alpha]^{25} \mathrm{D}+9.8^{\circ}$ (c 1.02, 
$\left.\mathrm{CHCl}_{3}\right)$. I ts EIMS (m/z 128, [M] $\left.]^{+}\right)$together with NMR data reveal ed the molecular formula $\mathrm{C}_{6} \mathrm{H}_{8} \mathrm{O}_{3}$. Compound 6 was found to possess hydroxyl (IR $v_{\max } 3422 \mathrm{~cm}^{-1}$; EIMS m/z $110\left[\mathrm{M}-\mathrm{H}_{2} \mathrm{O}\right]^{+}$) and ester carbonyl (IR $v_{\max } 1746 \mathrm{~cm}^{-1}$. ${ }^{13} \mathrm{C}$ NMR $\left.\delta 172.5, \mathrm{C}\right)$ moieties. A conjugated cis-1,2disubstituted double bond was also assigned $\left({ }^{13} \mathrm{C}\right.$ NMR $\delta$ $122.1(\mathrm{CH})$ and $158.1(\mathrm{CH}) ;{ }^{1} \mathrm{H}$ NMR $\delta 6.12$ and 7.38, each $1 \mathrm{H}, \mathrm{d}, \mathrm{J}=5.7 \mathrm{~Hz}$ for both protons). Moreover, the ${ }^{1} \mathrm{H} \mathrm{NMR}$ data of $\mathbf{6}$ showed two $1 \mathrm{H}$ doublet signals of an oxymethylene at $\delta 3.70$ and 3.80 (each $\mathrm{d}, \mathrm{J}=12.0 \mathrm{~Hz}$ ) and one $3 \mathrm{H}$ singlet of a tertiary methyl at $\delta 1.48$, which were found to be correlated with the signals of the fully substituted oxycarbon at $\delta 89.3$ (C) and the olefinic methine carbon at $\delta 158.1$ in the HMBC spectrum (Figure 1). Comparison of NMR spectral data of $\mathbf{6}$ (see Experimental Section) with those of the known synthesized compound $15^{19}$ established the identity of $\mathbf{6}$ and $\mathbf{1 5}$. Therefore, on the basis of the sign of its optical activity, compound $\mathbf{6}$ was established as (+)5-hydroxymethyl-5-methylfuran-2-one.

Furthermore, 7, a less polar compound relative to 6 , was al so obtained as a col orless oil, $[\alpha]^{25} \mathrm{D}+21.4$ (c $0.28, \mathrm{CHCl}_{3}$ ). Its IR spectrum indicated the absence of the hydroxyl and the presence of the ester carbonyl $\left(v_{\max } 1740 \mathrm{~cm}^{-1}\right)$. NMR spectral data (see Experimental Section) indicated that 7 is simply an acetylated derivative of $\mathbf{6}$, as shown by the presence of additional carbon signals at $\delta 20.6\left(\mathrm{CH}_{3}\right)$ and $170.4(\mathrm{C}=\mathrm{O}$ of ester) and a proton signal at $\delta 2.05(3 \mathrm{H}, \mathrm{s}$, $\mathrm{OCOCH}_{3}$ ). According to the sign of the optical rotation, the structure of $\mathbf{7}$ was thus established as (+)-5-acetoxymethyl5-methylfuran-2-one.

It is noteworthy to mention that the novel metabolite 2 represents the first example of a 13-nor-9-epi- $\beta$-caryophyllene compound, and $\mathbf{5}$ is the first 17-norxeniaphyllane based derivative reported. In contrast to the trans ring fused $\beta$-caryophyllenes, which are common natural me tabolites, the caryophyllenes with a cis ring junction are rarely found. ${ }^{13-17}$ To the best of our knowledge, the norsesquiterpenoid $\mathbf{2}$ is the fourth natural product of this series and is the first one isolated from a marine organism. Moreover, we report the isolation of furanones $\mathbf{6}$ and $\mathbf{7}$ for the first time from natural sources.

The new terpenoid metabolites (1-5) and the furanone derivative $\mathbf{6}$ were evaluated for their in vitro cytotoxic activity against a limited panel of cancer cell lines. The results showed that the xeniaphyllane-type diterpenoids $\mathbf{3}$ and $\mathbf{4}$ exhibited moderate cytotoxicities against $K B$ and Hepa59TNGH cell lines (ED 50 values of 7.3 and $7.6 \mu \mathrm{g} /$ $\mathrm{mL}$ against the growth of $\mathrm{KB}$ cells and 4.5 and $8.3 \mu \mathrm{g} / \mathrm{mL}$ against the growth of Hepa59TNGH cells, respectively). Norditerpenoid $\mathbf{5}$ exhibited weak activity against Hela, $\mathrm{NCl}-\mathrm{H} 661$, and $\mathrm{KB}$ cells $\left(\mathrm{ED}_{50}\right.$ values of $15.9,19.0$, and 19.5 $\mu \mathrm{g} / \mathrm{mL}$, respectively) and was inactive toward Hepa59T/ VGH and Med cell lines. It was also found that the cis ring fused $\beta$-caryophyllene-type norsesquiterpenoid $\mathbf{2}$ exhibited only weak cytotoxicity against DLD-1 and Hepa59T/NGH $\left(E_{50}\right.$ values of 16.9 and $18.5 \mu \mathrm{g} / \mathrm{mL}$, respectively), while the trans ring fused related metabolite 1 showed no activity against the above six cancer cell lines. Moreover, furanone 6 was found to show only weak activity against NC-H661 cancer cells, with a $E D_{50}$ value of $15.7 \mu \mathrm{g} / \mathrm{mL}$.

\section{Experimental Section}

General Experimental Procedures. Optical rotations were measured on a J asco DI P-1000 digital polarimeter. IR spectra were recorded on a J asco FT-5300 infrared spectrophotometer. NMR spectra were recorded on a Bruker Avance DPX300 FT-NMR at $300 \mathrm{MHz}$ for ${ }^{1} \mathrm{H}$ and $75 \mathrm{MHz}$ for ${ }^{13} \mathrm{C}$ or on a Varian Unity INOVA $500 \mathrm{FT}-\mathrm{NMR}$ at $500 \mathrm{MHz}$ for ${ }^{1} \mathrm{H}$ and $125 \mathrm{MHz}$ for ${ }^{13} \mathrm{C}$, respectively, in $\mathrm{CDCl}_{3}$ using TMS as internal standard. EIMS was obtained with a VG Quattro GC/ MS spectrometer. HRMS spectra were recorded on a Finnigan MAT-95XL mass spectrometer. Silica gel (Merck, 230-400 mesh) was used for column chromatography. Precoated silica gel plates (Merck, Kieselgel $60 \mathrm{~F}-254,0.2 \mathrm{~mm}$ ) were used for analytical TLC.

Organism. S. nanol obata was collected by hand via scuba off the coast of southern Pingtung, Taiwan, in February 2001, at a depth of 15-20 m, and stored in a freezer until extraction. A voucher sample was deposited at the Department of Marine Resources, National Sun Yat-Sen University (specimen no. $\mathrm{SC003).}$

Extraction and Isolation. The Iyophilized bodies of S nanolobata (1.2 kg, wet wt) were minced and extracted exhaustively with $n$-hexane $(1 \mathrm{~L} \times 5)$ and then with dichloromethane $(0.4 \mathrm{~L} \times 3)$. The residue of dichloromethane layer was further extracted with n-hexane. The combined n-hexane extract was evaporated under vacuum to yield an oily residue (9.6 g), which was chromatographed over silica gel, using n-hexane, an n-hexane and EtOAc mixture of increasing polarity, then EtOAc-MeOH (stepwise, 100:0 to 50:50) to yield 28 fractions. Fraction 6, eluting with n-hexane-EtOAc (9:1), was chromatographed by normal-phase HPLC using a $\mathrm{CH}_{2-}$ $\mathrm{Cl}_{2}-\mathrm{MeOH}$ gradient (99:1 to $\left.97: 3\right)$ to yield $\mathbf{5}(2.0 \mathrm{mg})$. Fraction 12 , eluting with n-hexane-EtOAc (7:3), was purified by normal-phase HPLC using n-hexane-EtOAc (4:1) to afford 7 $(2.5 \mathrm{mg})$. Fractions 13 and 14, eluting with n-hexane-EtOAC (1:1), were separately purified by normal-phase HPLC using n-hexane-EtOAc (3:1) to afford 4 (11.4 mg) and $\mathbf{3}$ (5.8 mg), respectively. Fraction 21, eluting with EtOAc, was further separated by normal-phase HPLC using n-hexane-acetone (4:1 to 3:1) to give 2 (10.2 mg), 1 (18.5 mg), and 6 (9.6 mg).

Nanonorcaryophyllene A (1): colorless oil; $[\alpha]^{25} \mathrm{D}+42.6^{\circ}$ (c 1.48, $\mathrm{CHCl}_{3}$ ); IR (neat) $v_{\max } 3371,2968,2928,2878,1541$, 1456, 1299, $1219 \mathrm{~cm}^{-1} ;{ }^{1} \mathrm{H}$ NMR $\left(\mathrm{CDCl}_{3}, 300 \mathrm{MHz}\right)$ and ${ }^{13} \mathrm{C}$ NMR $\left(\mathrm{CDCl}_{3}, 75 \mathrm{MHz}\right)$, see Tables 1 and 3, respectively; EIMS $\mathrm{m} / \mathrm{z} 222\left(0.2,[\mathrm{M}]^{+}\right), 204\left(0.3,\left[\mathrm{M}-\mathrm{H}_{2} \mathrm{O}\right]^{+}\right), 189(0.8,[\mathrm{M}-\mathrm{Me}$ $\left.-\mathrm{H}_{2} \mathrm{O}\right]^{+}$), 149 (14.9), 121 (31.0); HREI MS m/z 222.1617 (calcd for $\mathrm{C}_{14} \mathrm{H}_{22} \mathrm{O}_{2}, 222.1622$ ).

Nanonorcaryophyllene B (2): colorless oil; $[\alpha]^{25}{ }_{D}-7.6^{\circ}$ (c $0.92, \mathrm{CHCl}_{3}$ ); I R (neat) $v_{\max } 3422,2948,2928,2878,1700$, 1647, 1541, $1456 \mathrm{~cm}^{-1}$; ${ }^{1} \mathrm{H} \mathrm{NMR}\left(\mathrm{CDCl}_{3}, 300 \mathrm{MHz}\right)$ and ${ }^{13} \mathrm{C}$ $\mathrm{NMR}\left(\mathrm{CDCl}_{3}, 75 \mathrm{MHz}\right)$, see Tables 1 and 3, respectively; EI MS $\mathrm{m} / \mathrm{z} 222\left(0.2,[\mathrm{M}]^{+}\right), 204\left(1.1,\left[\mathrm{M}-\mathrm{H}_{2} \mathrm{O}\right]^{+}\right), 189(2.2,[\mathrm{M}-\mathrm{Me}$ $-\mathrm{H}_{2} \mathrm{O}^{+}$), 149 (14.9), 161 (11.3), 146 (12.6), 131 (14.5); HREIMS m/z 222.1618 (calcd for $\mathrm{C}_{14} \mathrm{H}_{22} \mathrm{O}_{2}, 222.1622$ ).

Nanolobatin A (3): colorless oil; $[\alpha]^{25} \mathrm{D}+15.0^{\circ}$ (c 1.60 , $\mathrm{CHCl}_{3}$ ); IR (neat) $v_{\max } 3437,3011,2981,2934,2874,1632$ 1454, 1381, 1373, 997, $896 \mathrm{~cm}^{-1}$; ${ }^{1} \mathrm{H} \mathrm{NMR}\left(\mathrm{CDCl}_{3}, 300 \mathrm{MHz}\right)$ and ${ }^{13} \mathrm{C} \mathrm{NMR}\left(\mathrm{CDCl}_{3}, 75 \mathrm{MHz}\right)$, see Tables 1 and 2 , respectively; EIMS (30 eV) m/z $304\left(0.2,[M]^{+}\right), 286\left(0.4,\left[M-\mathrm{H}_{2} \mathrm{O}\right]^{+}\right)$, $271\left(1.0,\left[\mathrm{M}-\mathrm{Me}-\mathrm{H}_{2} \mathrm{O}\right]^{+}\right), 256(0.8), 241(0.6), 205$ (2.7), 149 (11.7), 135 (12.4); HREIMS m/z 304.2404 (calcd for $\left.\mathrm{C}_{20} \mathrm{H}_{32} \mathrm{O}_{2}, 304.2404\right)$.

Nanolobatin B (4): colorless oil; $[\alpha]^{25} \mathrm{D}+66.7^{\circ}$ (c 0.60 , $\mathrm{CHCl}_{3}$ ); IR (neat) $v_{\max } 3640,3025,2965,2935,2875,1709$, 1689, 1630, 1452, 1379, 1037, $902 \mathrm{~cm}^{-1}$; ${ }^{1} \mathrm{H}$ NMR $\left(\mathrm{CDCl}_{3}, 300\right.$ $\mathrm{MHz})$ and ${ }^{13} \mathrm{C} \mathrm{NMR}\left(\mathrm{CDCl}_{3}, 75 \mathrm{MHz}\right)$, see Tables 1 and 2, respectively; FABMS m/z $341\left(0.4,[\mathrm{M}+\mathrm{Na}]^{+}\right), 319(0.2,[\mathrm{M}+$ $\left.\mathrm{H}]^{+}\right), 304\left(0.5,[\mathrm{M}-\mathrm{Me}+\mathrm{H}]^{+}\right), 301\left(0.5,\left[\mathrm{M}-\mathrm{H}_{2} \mathrm{O}+\mathrm{H}^{+}\right)\right.$, $286\left(0.5,\left[\mathrm{M}-\mathrm{Me}-\mathrm{H}_{2} \mathrm{O}+\mathrm{H}\right]^{+}\right)$; HREIMS m/z 318.2394 (calcd for $\left.\mathrm{C}_{20} \mathrm{H}_{30} \mathrm{O}_{3}, 318.2196\right)$

Nanolobatin C (5): colorless oil; $[\alpha]^{25} \mathrm{D}+21.0^{\circ}$ (c 0.92 $\mathrm{CHCl}_{3}$ ); IR (neat) $v_{\max } 2970,2936,2875,1734,1700,1635$, $1541,1456,1375,1244,1039,960 \mathrm{~cm}^{-1}$; ${ }^{1} \mathrm{H}$ NMR $\left(\mathrm{CDCl}_{3}, 500\right.$ $\mathrm{MHz})$ and ${ }^{13} \mathrm{C} \mathrm{NMR}\left(\mathrm{CDCl}_{3}, 100 \mathrm{MHz}\right)$, see Tables 1 and 2, respectively; FABMS m/z $371\left(2.0,[\mathrm{M}+\mathrm{Na}]^{+}\right), 349(5.5,[\mathrm{M}+$ $\left.\mathrm{H}^{+}\right), 289\left(15.8,\left[\mathrm{M}-\mathrm{AcOH}+\mathrm{H}^{+}\right), 154\right.$ (71.1); HREIMS m/z 288.2083 (calcd for $\mathrm{C}_{21} \mathrm{H}_{32} \mathrm{O}_{4}-\mathrm{AcOH}, 288.2084$ ).

(+)-5-Hydroxymethyl-5-methylfuran-2-one (6): col orless oil; $[\alpha]^{25} \mathrm{D}+9.8^{\circ}$ (c 1.02, $\mathrm{CHCl}_{3}$ ); IR (neat) $v_{\max } 3422,2924,2852$, 1746, 1647, 1458, 1219, 1119, 1055, $956 \mathrm{~cm}^{-1}$; ${ }^{1} \mathrm{H} \mathrm{NMR}\left(\mathrm{CDCl}_{3}\right.$, $300 \mathrm{MHz}) 7.38(1 \mathrm{H}, \mathrm{d}, \mathrm{J}=5.7, \mathrm{H}-4), 6.12(1 \mathrm{H}, \mathrm{d}, \mathrm{J}=5.7, \mathrm{H}-3)$, 
$3.80(1 \mathrm{H}, \mathrm{d}, \mathrm{J}=12.0, \mathrm{H}-7), 3.70(1 \mathrm{H}, \mathrm{d}, \mathrm{J}=12.0, \mathrm{H}-7), 1.48$ $\left(3 \mathrm{H}, \mathrm{S}, \mathrm{H}_{3}-6\right) ;{ }^{13} \mathrm{C} \mathrm{NMR}\left(\mathrm{CDCl}_{3}, 75 \mathrm{MHz}\right) 172.5$ (C, C-5), 158.1 (CH, C-4), 122.1 (CH, C-3), 89.3 (C, C-5), $66.5\left(\mathrm{CH}_{2}, \mathrm{C}-7\right), 20.1$ $\left(\mathrm{CH}_{3}, \mathrm{C}-6\right)$; EIMS m/z $128\left(2.3,[\mathrm{M}]^{+}\right), 113\left(0.5,\left[\mathrm{M}-\mathrm{Me}^{+}\right)\right.$, 110 (1.8, [M $\left.-\mathrm{H}_{2} \mathrm{O}\right]^{+}$), 98 (100.0), 97 (83.4); HREIMS m/z 129.0549 (calcd for $\mathrm{C}_{6} \mathrm{H}_{9} \mathrm{O}_{4}, 129.0546$ ).

(+)-5-Acetoxymethyl-5-methylfuran-2-one (7): colorless oil; $[\alpha]^{25} \mathrm{D}+21.5^{\circ}$ (c $0.28, \mathrm{CHCl}_{3}$ ); IR (neat) $v_{\max } 2955,2926$, 2866, 1740, 1659, 1611, 1458, 1375, 1165, 1020, 885, $814 \mathrm{~cm}^{-1}$. ${ }^{1} \mathrm{H} \mathrm{NMR}\left(\mathrm{CDCl}_{3}, 300 \mathrm{MHz}\right) 7.33(1 \mathrm{H}, \mathrm{d}, \mathrm{J}=5.7, \mathrm{H}-4), 6.10$ $(1 \mathrm{H}, \mathrm{d}, \mathrm{J}=5.7, \mathrm{H}-3), 4.34(1 \mathrm{H}, \mathrm{d}, \mathrm{J}=11.7, \mathrm{H}-7), 4.17(1 \mathrm{H}, \mathrm{d}$ $\mathrm{J}=11.7, \mathrm{H}-7), 2.05\left(3 \mathrm{H}, \mathrm{s}, \mathrm{OCOCH}_{3}\right), 1.15\left(3 \mathrm{H}, \mathrm{s}, \mathrm{H}_{3}-6\right) ;{ }^{13} \mathrm{C}$ NMR (CDCl $3,75 \mathrm{MHz}) 171.8$ (C, C-2), 170.4 (C, Ac-carbonyl), $156.9(\mathrm{CH}, \mathrm{C}-4), 122.2(\mathrm{CH}, \mathrm{C}-3), 86.8(\mathrm{C}, \mathrm{C}-5), 65.8\left(\mathrm{CH}_{2}, \mathrm{C}-7\right)$, $20.8\left(\mathrm{CH}_{3}, \mathrm{C}-6\right), 20.6\left(\mathrm{CH}_{3}, \mathrm{AC}-\mathrm{Me}\right) ; \mathrm{EIMS} \mathrm{m} / \mathrm{z} 170\left(0.1,[\mathrm{M}]^{+}\right)$, $155\left(1.5,\left[\mathrm{M}-\mathrm{Me}^{+}\right), 134\right.$ (58.1), $110\left(3.4,[\mathrm{M}-\mathrm{ACOH}]^{+}\right), 98$ (100.0).

Cytotoxicity Testing. Cell lines were purchased from the American Type Culture Collection (ATCC). Cytotoxicity assays of the test compounds $\mathbf{1 - 5}$ and $\mathbf{7}$ were performed using the MTT [3-(4,5-dimethylthiazole-2-yl)-2,5-diphenyltetrazolium bromide] col orimetric method. ${ }^{20,21}$

Acknowledgment. This work was supported by a grant from the National Science Council of the Republic of China (Contract No. NSC-90-2323-B-110-003) awarded to J .-H.S.

\section{References and Notes}

(1) Faulkner, D. J . Nat. Prod. Rep. 2002, 19, 1-48, and previous reports in this series.

(2) Sheu, J .-H.; Ahmed, A. F.; Shiue, R.-T.; Dai, C.-F .; Kuo, Y.-H.J . Nat. Prod. 2002, 65, 1904-1908, and references therein.
(3) Yamada, K.; Ujie, T.; Yoshida, K.; Miyamoto, T.; Higuchi, R. Tetrahedron 1997, 53, 4569-4578.

(4) Sheu, J.-H.; Sung, P.-J .; Su, J.-H.; Duh, C.-Y.; Chiang, M. Y. Tetrahedron 1999, 55, 14555-14564.

(5) Sheu, J.-H.; Chen S.-P.; Sung, P.-J.; Chiang, M. Y.; Dai, C.-F. Tetrahedron Lett. 2000, 41, 7885-7888.

(6) Sung, P.-J .; Su, J .-H.; Duh, C.-Y.; Chiang, M. Y.; Sheu, J .-H. J . Nat Prod. 2001, 64, 318-323.

(7) Wang, G.-H.; Ahmed, A. F.; Sheu J .-H.; Duh C.-Y.; Shen Y.-C.; Wang, L.-T. J . Nat. Prod. 2002, 65, 887-891.

(8) Ahond, A.; Bowden, B. F.; Coll, J . C.; Fourneron, J .-D.; Mitchell, S. J. Aust. J . Chem. 1981, 34, 2657-2664.

(9) Groweiss, A.; Kashman, Y. Tetrahedron 1983, 39, 3385-3396, and references therein.

(10) König, G. M.; Wright, A. D. J . Nat. Prod. 1993, 56, 2198-2200.

(11) Thebtaranonth, C.; Thebtaranonth, Y.; Wanauppathamkul, S. Yuthavong, Y. Phytochemistry 1995, 40, 125-128.

(12) Abraham, W.-R.; Ernst, L.; Stumpf, B. Phytochemistry 1990, 29, 115120.

(13) Bohlmann, F.; Zdero, C. Phytochemistry 1978, 17, 1135-1153.

(14) Bohlmann, F.; Ziesche, J. Phytochemistry 1981, 20, 469-472.

(15) Berry, K. M.; Perry, N. B.; Weavers, R. T. Phytochemistry 1985, 24, 2893-2898.

(16) Hinkley, S. F. R.; Perry, N. B.; Weavers, R. T. Phytochemistry 1994, 35, 1489-1494.

(17) Barrero, A. F.; Sánchez, J . F .; Ferrol, N. Tetrahedron Lett. 1989, 30, 247-250.

(18) Demirci, B.; Baser, K. H. C.; Demirci, F.; Hamann, M. T.J . Nat. Prod. 2000, 63, 902-904.

(19) Ohe, K.; Takahashi, H.; Uemura, S.; Sugita, N.J . Org. Chem. 1987, 52, 4859-4863.

(20) Alley, M. C.; Scudiero, D. A.; Monks, A.; Hursey, M. L.; Czerwinski, M. J .; Fine, D. L.; Abbott, B. J .; Mayo, J . G.; Shoemaker, R. H.; Boyd M. R. Cancer Res. 1988, 48, 589-601.

(21) Scudiero, D. A.; Shoemaker, R. H.; Paull, K. D.; Monks, A.; Tierney, S.; N ofziger, T. H.; Currens, M. J .; Seniff, D.; Boyd, M. R. Cancer Res. 1988, 48, 4827-4833.

NP030286W 